\title{
Increasing the Pensionable Age: What Changes Are OECD Countries Making? What Considerations Are Driving Policy?
}

\author{
Hila Axelrad1, Kevin J. Mahoney² \\ ${ }^{1}$ Center on Aging \& Work, Boston College, Chestnut Hill, MA, USA \\ ${ }^{2}$ School of Social Work, Boston College, Chestnut Hill, MA, USA \\ Email: axelradh@bc.edu
}

How to cite this paper: Axelrad, H. and Mahoney, K.J. (2017) Increasing the Pensionable Age: What Changes Are OECD Countries Making? What Considerations Are Driving Policy? Open Journal of Social Sciences, 5, 56-70.

https://doi.org/10.4236/jss.2017.57005

Received: May 13, 2017

Accepted: July 9, 2017

Published: July 12, 2017

Copyright $\odot 2017$ by authors and Scientific Research Publishing Inc. This work is licensed under the Creative Commons Attribution International License (CC BY 4.0).

http://creativecommons.org/licenses/by/4.0/

\begin{abstract}
The average age of retirement used to be low in most countries due to numerous policies introduced 30 to 40 years ago which encouraged lower retirement ages. However, in response to the growth of the older segment of the population, increased life expectancy, the need for skilled workers, and the precarious financial state of public pension systems, pension reforms have been implemented in the U.S. and Europe, and are now geared towards improving employment rates for older workers, increasing retirement ages and pension eligibility. This paper surveys recent changes in retirement age and maps the changes that have occurred in the last decades using data from 34 OECD (The Organization for Economic Co-operation and Development) countries. This paper then reviews the arguments for and against these changes, the criteria for setting a certain retirement age, and the differences in statutory retirement age by gender, occupation, employment status, and other factors unique to particular countries. The purpose of this paper is to analyze current trends in terms of raising the pensionable age.
\end{abstract}

\section{Keywords}

Retirement, Retirement Age, International Comparison, Policy, Early Retirement

\section{Introduction}

In the last decade, the trend of decreasing retirement age and early exit from the labor market [1] [2] has begun to change [3] [4]. In response to the growth of the older segment of the population and the unstable financial state of many of the public pension systems [5] [6] [7], the costs of early retirement have come under increased scrutiny. Such costs have led to a string of pension reforms in 
Europe since the 1990s, cutting back on pay-as-you-go pension benefits and introducing multi-pillar pension systems with supplemental occupational and individual pensions in addition to the traditional unfunded retirement insurance [8] [9]. Public policy is now geared toward improving employment rates for older workers [3] [4] and extending working years. According to the Organization for Economic Co-operation and Development (OECD), by 2050, the average pensionable age in OECD countries will reach nearly 65 for both sexes: an increase of nearly 2.5 years for men and 4 years for women compared to 2010. For example, Australia, Denmark, France, and Germany implemented measures to increase their normal retirement age from sixty-five to sixty-seven (Table 1) [10]. However, life expectancy is projected to grow at a faster rate than these increases in pension age [11]. In general we can say that social security systems in different countries were designed and influenced by each country's prevailing culture, social priorities and economic capacity at the time [12] [13]. It is crucial to understand differences between country's retirement ages as well as which cohort(s) will pay for future pensions.

The two major benefits of raising the retirement age are reducing the long term deficit in the social security pension funds and promoting general economic gains [6]. But doing so can also increase the burden on public programs that provide a safety net for those who cannot, or prefer not to, keep working. In Austria, and Australia, for example, pension reforms increased the age of eligibility, reduced early retirement, but also increased disability insurance claims and enrollment in other social insurance programs [14] [15].

The motivations driving all these various governments are similar; people are living longer and therefore, are drawing retirement benefits for longer periods. Extended payouts have placed significant strain on pension programs, and as a result, benefit cuts and higher ages of eligibility for retirement benefits are becoming the norm. Absent tax increases or benefit cuts, these types of changes may be necessary. Without addressing this issue, governments will not be able to pay for more people needing retirement funds for longer periods of time.

This paper documents the changes that have occurred in the last decade using data from the 34 OECD countries: Australia, Austria, Belgium, Canada, Chile, Czech Republic, Denmark, Estonia, Finland, France, Germany, Greece, Hungary, Iceland, Ireland, Israel, Italy, Japan, South Korea, Luxembourg, Mexico, Netherlands, New Zealand, Norway, Poland, Portugal, Slovakia, Slovenia, Spain, Sweden, Switzerland, Turkey, UK and U.S. (Table 1). This manuscript provides a review of the changes in retirement age in those countries, the arguments for and against these changes, the criteria for setting a certain retirement age, and the differences in the statutory retirement age between males and females. The contribution of this paper is bringing together the current changes in the retirement ages and analyzing the reasons behind these increases.

As reflected in Table 1, and according to the OECD and the International Social Security Administration, 19 countries have increased retirement age, among them 7 of the countries (Australia, Belgium, Greece, Estonia, Slovenia, Switzer- 
Table 1. Changes in retirement age through time.

\begin{tabular}{|c|c|c|c|c|c|c|c|c|c|}
\hline & & 2002 & 2004 & 2006 & 2008 & 2010 & 2012 & 2014 & 2016 \\
\hline \multirow[t]{2}{*}{ Australia } & Male & 65 & 65 & 65 & 65 & 65 & 65 & 65 & 65 \\
\hline & Female & 62.5 & 62.5 & 63 & 63 & 64 & 64.5 & 65 & 65 \\
\hline \multirow[t]{2}{*}{ Austria } & Male & 65 & 65 & 65 & 65 & 65 & 65 & 65 & 65 \\
\hline & Female & 60 & 60 & 60 & 60 & 60 & 60 & 60 & 60 \\
\hline \multirow[t]{2}{*}{ Belgium } & Male & 65 & 65 & 65 & 65 & 65 & 65 & 65 & 65 \\
\hline & Female & 62 & 63 & 64 & 64 & 65 & 65 & 65 & 65 \\
\hline \multirow[t]{2}{*}{ Canada } & Male & 65 & 65 & 65 & 65 & 65 & 65 & 65 & 65 \\
\hline & Female & 65 & 65 & 65 & 65 & 65 & 65 & 65 & 65 \\
\hline \multirow[t]{2}{*}{ Chile } & Male & 65 & 65 & 65 & 65 & 65 & 65 & 65 & 65 \\
\hline & Female & 60 & 60 & 60 & 60 & 60 & 60 & 60 & 60 \\
\hline \multirow{2}{*}{ Czech Republic } & Male & 61.2 & 61.5 & 61.5 & 61.8 & 62.2 & 62.5 & 62.7 & 63 \\
\hline & Female & $55.3 / 9.3$ & $56-60$ & 55.7 & 56.33 & 60.67 & 61.33 & 61.3 & 62.3 \\
\hline \multirow[t]{2}{*}{ Denmark } & Male & 67 & $67^{1}$ & 65 & 65 & 65 & 65 & 65 & 65 \\
\hline & Female & 67 & $67^{1}$ & 65 & 65 & 65 & 65 & 65 & 65 \\
\hline \multirow[t]{2}{*}{ Estonia } & Male & 63 & 63 & 63 & 63 & 63 & 63 & 63 & 63 \\
\hline & Female & 58 & 59 & 59.5 & 60.5 & 61 & 61 & 61 & 63 \\
\hline \multirow[t]{2}{*}{ Finland } & Male & 65 & 65 & 65 & 65 & 65 & 65 & 65 & 65 \\
\hline & Female & 65 & 65 & 65 & 65 & 65 & 65 & 65 & 65 \\
\hline \multirow[t]{2}{*}{ France } & Male & 60 & 60 & 60 & 60 & 60 & 60 & 61.1 & 61.6 \\
\hline & Female & 60 & 60 & 60 & 60 & 60 & 60 & 61.1 & 61.6 \\
\hline \multirow[t]{2}{*}{ Germany } & Male & 65 & 65 & 65 & 65 & 65 & 65.1 & 65.3 & 65.4 \\
\hline & Female & 65 & 65 & 65 & 65 & 65 & 65.1 & 65.3 & 65.4 \\
\hline \multirow[t]{2}{*}{ Greece } & Male & 65 & 65 & 65 & 65 & 65 & 65 & 67 & 67 \\
\hline & Female & 60 & 60 & 60 & 60 & 60 & 62 & 62 & 62 \\
\hline \multirow[t]{2}{*}{ Hungary } & Male & 62 & 62 & 62 & 62 & 62 & 62.5 & 62.5 & 63.5 \\
\hline & Female & $55-62$ & 59 & 60 & 61 & 62 & & other criteria & other criteria \\
\hline \multirow[t]{2}{*}{ Iceland } & Male & 67 & 67 & 67 & 67 & 67 & 67 & 67 & 67 \\
\hline & Female & 67 & 67 & 67 & 67 & 67 & 67 & 67 & 67 \\
\hline \multirow[t]{2}{*}{ Ireland } & Male & 66 & 66 & 65 & 65 & 65 & $65-66$ & 66 & 66 \\
\hline & Female & 66 & 66 & 65 & 65 & 65 & $65-66$ & 66 & 66 \\
\hline \multirow[t]{2}{*}{ Israel } & Male & 65 & 65 & 66 & 66.7 & 67 & 67 & 67 & 67 \\
\hline & Female & 60 & 60 & 61 & 61.7 & 62 & 62 & 62 & 62 \\
\hline \multirow[t]{2}{*}{ Italy } & Male & 65 & 65 & 65 & 65 & 65 & 66 & 66.3 & 66.6 \\
\hline & Female & 60 & 60 & 60 & 60 & 60 & 66 & 66.3 & $66.6^{6}$ \\
\hline \multirow[t]{2}{*}{ Japan } & Male & 65 & 65 & 65 & 65 & 65 & 65 & 65 & 65 \\
\hline & Female & 65 & 65 & 65 & 65 & 65 & 65 & 65 & 65 \\
\hline South Korea & Male & & & & & 60 & 60 & 61 & 61 \\
\hline
\end{tabular}


Continued

\begin{tabular}{|c|c|c|c|c|c|c|c|c|c|}
\hline & Female & & & & & 60 & 60 & 61 & 61 \\
\hline \multirow[t]{2}{*}{ Luxembourg } & Male & 65 & 65 & 65 & 65 & 65 & 65 & 65 & 65 \\
\hline & Female & 65 & 65 & 65 & 65 & 65 & 65 & 65 & 65 \\
\hline \multirow[t]{2}{*}{ Mexico } & Male & 65 & 65 & 65 & 65 & 65 & 65 & 65 & 65 \\
\hline & Female & 65 & 65 & 65 & 65 & 65 & 65 & 65 & 65 \\
\hline \multirow[t]{2}{*}{ Netherlands } & Male & 65 & 65 & 65 & 65 & 65 & 65 & 65.2 & 65.5 \\
\hline & Female & 65 & 65 & 65 & 65 & 65 & 65 & 65.2 & 65.5 \\
\hline \multirow[t]{2}{*}{ N. Zealand } & Male & 65 & 65 & 65 & 65 & 65 & 65 & 65 & 65 \\
\hline & Female & 65 & 65 & 65 & 65 & 65 & 65 & 65 & 65 \\
\hline \multirow[t]{2}{*}{ Norway } & Male & 67 & 67 & 67 & 67 & 67 & 67 & 67 & 67 \\
\hline & Female & 67 & 67 & 67 & 67 & 67 & 67 & 67 & 67 \\
\hline \multirow[t]{2}{*}{ Poland } & Male & 65 & 65 & 65 & 65 & 65 & 65 & 65 & 65 \\
\hline & Female & 60 & 60 & 60 & 60 & 60 & 60 & 60 & 60 \\
\hline \multirow[t]{2}{*}{ Portugal } & Male & 65 & 65 & 65 & 65 & 65 & 65 & 66 & 66.2 \\
\hline & Female & 65 & 65 & 65 & 65 & 65 & 65 & 66 & 66.2 \\
\hline \multirow[t]{2}{*}{ Slovakia } & Male & 60 & 62 & 62 & 62 & 62 & 62 & 62 & 62 \\
\hline & Female & $53-57^{2}$ & 62 & 55.3 & 56.8 & $62^{3}$ & $j 62^{3}$ & $62^{3}$ & 62 \\
\hline \multirow[t]{2}{*}{ Slovenia } & Male & $58-65^{4}$ & $58-65^{4}$ & $58-65^{4}$ & 62.5 & $58-65^{4}$ & $58-65^{4}$ & 65 & 65 \\
\hline & Female & $54-57^{4}$ & $54.7-62^{4}$ & $55.3-62.3^{4}$ & 56 & $56.7-63^{4}$ & $57.3-63^{4}$ & 65 & 65 \\
\hline \multirow[t]{2}{*}{ Spain } & Male & 65 & 65 & 65 & 65 & 65 & 65 & 65.2 & 65.3 \\
\hline & Female & 65 & 65 & 65 & 65 & 65 & 65 & 65.2 & 65.3 \\
\hline \multirow[t]{2}{*}{ Sweden } & Male & 65 & 65 & 65 & 65 & 65 & 65 & 65 & 65 \\
\hline & Female & 65 & 65 & 65 & 65 & 65 & 65 & 65 & 65 \\
\hline \multirow[t]{2}{*}{ Switzerland } & Male & 65 & 65 & 65 & 65 & 65 & 65 & 65 & 65 \\
\hline & Female & 63 & 63 & 64 & 64 & 64 & 64 & 64 & 64 \\
\hline \multirow[t]{2}{*}{ Turkey } & Male & & & & & & 60 & 60 & 60 \\
\hline & Female & & & & & & 58 & 58 & 58 \\
\hline \multirow[t]{2}{*}{ UK } & Male & 65 & 65 & 65 & 65 & 65 & 65 & 65 & 65 \\
\hline & Female & 60 & 60 & 60 & 60 & 60 & 61 & 62 & 63 \\
\hline \multirow[t]{2}{*}{ U.S. } & Male & 65 & 65 & 65 & 65 & 66 & 66 & 66 & 66 \\
\hline & Female & 65 & 65 & 65 & 65 & 66 & 66 & 66 & 66 \\
\hline
\end{tabular}

The gray shading indicates an increase in Pensionable Age. (1) 65 from July 2004. (2) According to the number of children raised. (3) The retirement age for certain women is rising gradually to age 62 by 2015. (4) According to the years of contribution. (5) 67, changed to 65 from July04. (6) Lower age (65 and seven months) for women in the private sector. Source: Processed by the authors by using data from Social Security U.S.A (International Social Security Association) [57].

land, UK) increased retirement age only for women. 20 countries are planning to increase retirement age in the next coming years, when the planned increase is range between 2 years (for example in Canada and Denmark) and 7 years (for example the retirement age for women in Poland and Turkey). 14 of the OECD countries have not increased retirement age. 


\section{How Was the Retirement Age Determined?}

Otto von Bismarck, the Prussian chancellor who implemented the world's first modern welfare state in the 1880 , was the first major government official to spell out a new role for government in securing the welfare of wage earners after their careers in a highly organized, industrial society. This new ideology spread through Europe before World War I, and arrived in the U.S. in 1935 [16].

There was no scientific or gerontological basis for setting the retirement age in the past [6]. Factors such as cost, life expectancy, ability to work and find employment were considered. Pension age was set at seventy when Bismarck implemented the pension insurance in 1989 [17], later on and until 1972, retirement was mandatory at the age of 65 [18]. In the US the age of sixty five was selected, the reason for selecting the age of 65 was simply general consensus [6] as many other institutions like the union army veterans, post office letter carriers and clerks, Railroad etc. grant pensions had selected sixty-five years of age [19]. Additionally, the US, as many other countries, experienced declining labor force participation rates of men older than sixty-four since the end of the nineteenth century [19]. The prevailing notion among different researchers and policy makers was that worker's productivity declines significantly after the age of 60 or 65 as physical ability, mental alertness, and cooperativeness tend to fail [19] [20] so the retirement age was set between these ranges, although current studies showed that older workers are not necessarily less productive [21].

However, it should be remembered that full retirement is not always based solely on age. Qualifying to receive an old-age benefit is usually conditional on two requirements: attainment of a specified pensionable age and completion of a specified period of contributions or covered employment (for example Greece, Luxemburg, U.S.), since programs are financed entirely or largely from contributions (usually a percentage of earnings) made by employers, workers, or both. These contributions are compulsory in most instances for defined categories of workers and their employers.

Some old-age pension systems account for periods during which persons, for reasons beyond their control, were not in covered employment by awarding credits toward the required minimum contribution period. Credits can be awarded for reasons such as disability, involuntary unemployment, military service, education, child raising, or training. In the UK, for example, contributions may be credited for periods the insured cared for a child or an elderly or disabled relative or if the insured received certain benefits. Other systems disregard these periods and may proportionately reduce benefits for each year below the required minimum; for example, in Poland, non-contributory years (meaning years spent raising children or while receiving certain benefits) must not exceed $33.3 \%$ of contributory years. Persons with only a few years of coverage may receive a refund of contributions or a settlement in which a proportion of the full benefit or earnings is paid for each year of contribution.

In recent years, with the increase in the number of years until retirement, several countries have implemented changes in the required period of contribution 
(Czech Republic, Poland and Spain). For example in Spain, the required period of contribution is gradually rising from 35 years and 6 months to 37 years by 2027. The changes in the required period of contribution may also differ by gender-in Czech Republic the coverage years are gradually rising from 30 to 35 years for men, and at least 20 years of coverage for women (with no expected raise). In Poland men will need at least 25 years of coverage, women will need at least 21 years of coverage, and this is gradually rising to 25 years by 2022 .

Another common requirement is total or substantial withdrawal from the labor force. Some countries require complete or substantial retirement to become eligible for a pension (for example, Luxembourg and Portugal). Other countries pay a retirement pension at a certain age regardless of whether workers retire or not (Canada, Finland, Hungary, Italy, Norway). Other countries use a hybrid system with a retirement test, under which the benefit may be withheld or reduced for those who continue working, depending on the amount of earnings or, less often, the number of hours worked (Ireland and Spain). In the U.S., for example, Social Security beneficiaries age 62, age of earliest eligibility, until the age of eligibility for full benefits, have their benefits reduced if their earnings are above a certain threshold, but after the age of full retirement benefits, there is no penalty for continuing to work ${ }^{1}$. Universal systems usually do not require retirement from work for receipt of a pension. On the other hand, provident funds, which were created to provide financial security and stability, pay the benefit when the worker is temporarily or no longer fit to work or at retirement.

\section{The Criteria for Setting a Certain Retirement Age}

The old-age benefit in most countries (for example Switzerland and Turkey) is a wage-related, periodic payment. However, some countries pay a universal fixed amount that bears no relationship to any prior earnings; others supplement their universal pension with an earnings-related pension. Provident fund systems make a lump-sum payment (Poland) usually a refund of employer and employee contributions plus accrued interest. In programs that have individual accounts, options for benefits include purchasing an annuity (Estonia) making withdrawals from an account regulated to guarantee income for an expected lifespan; programmed withdrawals, or a combination of the two; and deferred annuity [22]. But age is not the only criteria for setting an official age for receiving retirement benefits: Public pension schemes sometimes distinguish on the basis of gender. Women often have earlier statutory retirement ages [23], even though they generally have a longer life expectancy [22]. Reduced retirement age for women can be seen in Israel [24] and Turkey, but no difference in the retirement age and conditions in countries like Belgium, Finland and the Netherlands. In other countries there are no differences between men and women in retirement age, but there are differences in terms and conditions-for example, the required years of coverage (as in Poland).

${ }^{1}$ Benefits that are reduced due to this "earnings test" are credited to beneficiaries when they reach the Full Retirement Age. 
Among the rationales for reduced age of eligibility for retirement benefits for females is the fact that wives are typically a few years younger than their husbands. Because couples often prefer to retire at the same time such policies would make the wife's benefits available at an earlier age [6]. Such policies also assume that retirement benefits should be available at an earlier age for working women because they face age barriers in the labor market more frequently and at earlier ages then do working men [6]. In some countries, the reason for reduced retirement age is being a mother. The retirement age is reduced according to the number of children raised (Czech Republic, Turkey) or reduced for mothers who have children with disabilities (Turkey).

Although the norm has been for the differential to be about five years, there is now an emerging international trend toward equalizing the statutory retirement age [22] presumably due to women's gains in equality rights. Additionally, the retirement age takes into account life expectancy, which is higher for women [25]. Thus, since men tend to work more years and their life expectancy is shorter than women's, they receive a pension for fewer years compared to women [26].

In some instances, eligibility for pension benefits is determined by resident status or citizenship. The person must be a resident of the country for a certain number of years (for example, Australia, Denmark, Estonia, the Netherlands and Sweden). Universal old-age pension is an example for a system that usually does not require a minimum period of covered employment or contributions, but do require a minimum period of prior residence (Denmark, Iceland).

Some countries, such as Germany and Spain, pay a full pension before the regular retirement age if the applicant experienced involuntary unemployment for a period near retirement age. In Portugal, there is reduced retirement age for unemployed persons who are no longer entitled to receive unemployment benefits. Also the type of employment can effect retirement age. In Turkey, for example, there are different conditions placed on the minimum number of days of paid contributions for civil servants and self-employed (9000 days of paid contributions, instead of 7200 days).

Another criterion is disability when some countries pay a full pension before the regular retirement age if the applicant has an assessed degree of disability (Germany, U.S.).

Occupation is relevant in other countries that pay a full pension before the regular retirement age, if the worker works in an especially arduous, strenuous environment or an unhealthy or hazardous occupation [23]. For example, the qualifying conditions are reduced for persons, who have worked in hazardous or dangerous work (Hungary, Spain). Other occupations with reduced ages of eligibility include miners (Poland), some categories of seamen (Iceland) and seafarers and civil aviation flight crews (Belgium).

\section{Reasons for Increasing the Retirement Age}

The main reason for increasing the retirement age is the demographic changes 
reflected in longer life expectancies [27] and therefore longer periods drawing on pensions. Other reasons that are often mentioned are the crisis in public pension programs, issues of supply and demand in the labor market, savings and retirement security of the older population, and the improved education level which is correlated with the ability to work longer.

\subsection{The Demographic Challenge}

Longer life expectancies [6] [28] are used as a justification for increasing retirement age as they are putting a burden on the financing system because benefits are being paid out for a longer period than in the past. In addition, fewer workers are dying before reaching retirement age; these workers had been a "free lunch" for the retirement system. Now fewer workers contribute without receiving at least some benefits. Increasing the retirement age will reduce the amount of time in which benefits are paid out, and increase the probability that a worker will receive no benefit, thus easing the stress in the system [10].

Many countries are facing this challenge of a rapidly ageing population. Life expectancy increased continuously over the past few decades; the period of time that seniors live after reaching retirement age grew from 13.4 years for men in 1958 to 18.5 in 2010. The OECD analysis of United Nations data projects life expectancy to be 20.3 years in retirement, even after the higher retirement ages are phased in [29].

Life-expectancy adjustment of the pension benefits can be seen as a substitute for increases in the pension age, in that many people can voluntarily work longer as life expectancy increases to make up for the lower yearly pension payments [30]. In the US, the amendment increasing the Full Retirement Age by two years was adopted in 1983, though the change only took effect 2003, and the full increase to 67 will not be realized until 2027 [31]. Phasing in the increased age of retirement gave people time to plan ahead. Furthermore, the change had no immediate effect and did not affect current retirees; all of these factors made it more politically palatable [32].

\subsection{Crisis in Public Pension Programs}

Public pension programs in many OECD countries are in financial trouble [6] part of this is because when pension systems were first implemented benefits were paid to individuals who had not contributed over a lifetime. But some of the problem came because many countries chose not to pre-fund. Pension reforms in some OECD countries [7] [33], link contributions of individuals and benefit rights accumulation.

As the ratio of workers to beneficiaries is projected to decline increasing pensionable age is a way to avoid heavier tax burden on the younger generation [6]. Increasing the pensionable age might encourage people to stay longer in the workforce, and this will result in greater net inflows through payroll taxes and improving solvency [10] [28]. 


\subsection{Greater Demand for Older Workers}

Older workers are in greater demand because fertility was low in subsequent generations and the talents of older workers are needed [6] [28]. Additionally, a decrease in physically demanding jobs and improved educational levels [34] allows many people to work longer [10] [22]. Health is better among the elderly than in previous generations, thereby allowing a longer work life for many [10]. The long-predicted wave of baby boomer retirements has begun to hit companies, leaving employers scrambling to find replacements for their departing sixty-something workers [35].

The demand for skilled older workers will remain high given that there are fewer younger workers to replace them [10]. On the other hand, many older individuals are underutilized relative to their potential productivity, and a higher pensionable age could contribute to a better and longer use of the skills and abilities of older workers [10] [36].The elderly stand to gain in noneconomic ways because employment may contribute to an older person's mental acuity and provide a sense of usefulness and social connection [10].

Whereas there had been some resistance from employers, Conen, Henkens and Schippers (2014) [37] who analyzed case studies among Dutch organizations found that employers have started to adjust to the rise in the official retirement age in terms of health and safety regulations, and increasing training for senior workers [38].

\subsection{Saving and Retirement Security}

One challenge of an aging population may be a growing number of increasingly long-lived individuals who outlive their retirement resources and will then rely on the social safety net to meet late-life needs. Raising retirement ages is one of the options for enhancing retirement security [39]. Working longer should improve the retirement savings of individuals, reducing the possibility of exhausting their resources in old age [10] [40].

\subsection{Improved Education Level}

Education levels have improved in labor markets around the world [34], research indicates that better educated people have lower morbidity rates from the most common acute and chronic diseases, independent of basic demographic and labor market factors [22], and a correlation exists between higher education and the ability to work longer [10]. Therefore, and as a result, the increase in the workers' education level could be a justification for increasing the retirement age.

The concept of active ageing implemented by the European Union suggested that older workers should have sufficient access to further education and training to help them remain active in the labor market [41].

To conclude, it can be said that increasing the retirement age can be efficient from the economic point of view, as by increasing the number of people in the labor force, gross domestic product will also increase thereby creating more re- 
sources that could be split between workers and retirees [10].

\section{Early Retirement}

There are workers who choose, for different reasons, to retire before the statutory retirement age is reached. "Early retirement" is an opportunity for phased reduction in the retirement benefits available earlier than the normal retirement age [42]. It is an opportunity to receive some benefits earlier. A reduced pension, in some instances, may be claimed up to five years before the statutory retirement age [22]. For example in Japan the pension is reduced by $42 \%$ to $11 \%$ (depending on the age at which the pension is awarded) when retiring before the official retirement age. On the other, in the US pension benefits is reduced for each month the insured is younger than the full retirement age, however the pension is increased by $8 \%$ a year for each year after one reaches full retirement age the insured defers retirement -up to the age of 70 years old.

Early retirement has broader implications for organizations and society as it represents an "off time" event (i.e., the timing of the event is inconsistent with the societal norms). As a result, from the human resource management perspective, organizations and society, more broadly, must account for the influence that early retirements have on other members of the organization or society [43]. Early retirement is also seen as a much appreciated social achievement which increases personal well-being, particularly among employees who suffer from work-related health problems [44].

A procedures distinction is made between workers that retire voluntarily, usually due to a strong preference for retirement, and involuntary retirees, who are forced to retire by such factors as health problems, weak employment conditions, and organizational pressures that induce them to leave their jobs [45].

As times changed, policymakers have started to increase not only the eligibility age of retirement, but also the eligibility age for early retirement [22]. For example, in Spain involuntary early retirement age is gradually rising from the age 61 and two months to age 63 by 2027 and voluntary early retirement age is rising from the 63 and two months to age 65 by 2027.

\section{Arguments against Increasing the Retirement Age}

The policy of increasing retirement age encountered in a widespread resistance from unions [46], women's rights organizations and others. In addition to disputing many of the contentions about increasing the retirement age, and the assumptions upon which they are made, the opponents' claim that the reduced benefits will increase the poverty rate because many of those at risk-the poor, the less educated, those with health problems, and those who work in physically demanding jobs-have no choice but to retire early [10].

Another argument made by the opponents is that not all groups have seen the same increase in life expectancy, so those with historically shorter life expectancies, for example the poor, the less educated, and blue collar workers-are affected disproportionally by an increase in the retirement age because they stand 
to reap fewer benefits [10]. In the U.S. for example, the average for the full population hides crucial differences between racial groups in quality of life, ability to work and longevity. Increasing the normal retirement age will make it more difficult for some Americans to experience a healthy and active retirement; Blacks will be disproportionately affected, in part because they are more likely to develop adverse health conditions that limit their ability to work and to report declining health. The average black American will experience physical limitations before the official retirement age of 67 [47].

Another reason for opposition is that older workers have more difficulty finding new employment and, when they do, often earn less than they did in previous jobs [10]. Women's rights organizations point out that women are discriminated against in the workplace [48]: they have a more difficult time getting a job, and when they do, they are paid less than a man doing the same work. These organizations feel that compelling women to work additional years will sentence them to more years of being a member of the working poor community, compelling many to rely on Social Security to supplement their income [32].

\section{Summary and Conclusions}

The growth of the older segment of the population together with increased life expectancy led policymakers to rethink the length of working life and pension eligibility age. As a result, in 24 of the 34 countries we examined, pension reforms increasing retirement ages were implemented or planned to be implemented in the near future.

Current data indicate that raising the retirement age may prevent serious challenges to the pension systems. In a situation where life expectancy is rising and people are living longer-and generally in good health-many older individuals want to or need to work. It should be also desirable from the employers' point of view, as shortage of workers becomes a serious problem in many places [49]. It therefore may be necessary to increase the retirement age.

With that being said, we should take into consideration the employers' point of view, as some employers may associate their ageing staff with higher labor costs and lower productivity [50] [51] while others are realizing their dependence on the skills of older workers. Employers that expect a larger cost- productivity gap might consider wage subsidies an effective measure to extend working lives [50].

We should also remember that there are vulnerable groups that are expected to suffer from any move to raise the retirement age. Therefore, if the policy of increasing the retirement age is implemented, it should be introduced incrementally to allow the public, employers and workers time to adjust to the changes. For example in Denmark, the retirement age will rise gradually by six months a year to 67 from 2024 to 2027. But it would not be enough; special attention must be given to disadvantaged populations and alternative forms of assistance should be arranged to help them cope during a longer period of time until they reach pension eligibility age. 
Countries can also implement other measures, together with or instead of increasing the retirement age. For example Sweden has not increased retirement age in recent years [52] [53] but created incentives for workers to remain employed longer [54]. Such incentives, like canceling the concept of "full pension" and implementing a new formula in which additional years one is gainfully employed increase the pension that person earn [55], or the option of drawing part of the worker pension while (s)he continues to work part-time, with his remaining pension entitlement continuing to grow [56], might prolong working life without implementing a raise in the retirement age.

The implications for policy makers are clear: first, there is a need to support changes that increase confidence in the solvency of the pension system while maintaining adequate protections; second, there is a need to analyze how each proposed change affects vulnerable populations and advocate for their protection. Finally, there is a need to educate and help people understand any changes in the law so they can plan ahead and decide about the optimal time to retire given their particular needs and preferences.

\section{Acknowledgements}

The authors would like to extend their sincere appreciation to Dr. Matthew S. Rutledge for his valuable comments and suggestions to improve the quality of the paper.

\section{References}

[1] Deacon, B. (2000) Eastern European Welfare States: The Impact of the Politics of Globalization. Journal of European Social Policy, 10, 146-161.

https://doi.org/10.1177/a012487

[2] D'addio, A.C. and Von Nordheim, F. (2014) Towards an Integrated Agenda to Deliver Effective Higher Retirement Ages: An Issues Note from the Pension Perspective. Paper Presented at the Background Note for the Workshop on "Delivering Longer Working Lives and Higher Retirement Ages", Brussels.

[3] Fisher, G.G., Chaffee, D.S. and Sonnega, A. (2016) Retirement Timing: A Review and Recommendations for Future Research. Work, Aging and Retirement, 2, 230261. https://doi.org/10.1093/workar/waw001

[4] Robinson, P. (2005) Working Later: Raising the Effective Age of Retirement Institute for Public Policy Research.

[5] Disney, R. (2000) Crises in Public Pension Programmes in OECD: What Are the Reform Options? The Economic Journal, 110, 1-23. https://doi.org/10.1111/1468-0297.00505

[6] Moore, K.L. (2001) Raising the Social Security Retirement Ages: Weighing the Costs and Benefits. Arizona State Law Journal, 33, 543.

[7] Wagner, H. (2005) Pension Reform in the New EU Member States: Will a ThreePillar Pension System Work? Eastern European Economics, 43, 27-51.

[8] Börsch-Supan, A.H. (2012) Entitlement Reforms in Europe: Policy Mixes in the Current Pension Reform Process. NBER, Working Paper No. 18009. https://doi.org/10.3386/w18009

[9] Fraccaroli, F. and Deller, J. (2015) Work, Aging, and Retirement in Europe: Intro- 
duction to the Special Issue. Work, Aging and Retirement, 1, 237-242. https://doi.org/10.1093/workar/wav017

[10] Templin, B.A. (2011) Social Security Reform: Should the Retirement Age Be Increased? Oregon Law Review, 89, 1179. http://ssrn.com/abstract $=1720402$

[11] Organization for Economic Co-Operation and Development (2011) Pensionable Age and Life Expectancy, 1950-2050. OECD Pension at a Glance. Organization for Economic Co-Operation and Development, Paris, 19-37.

[12] Fehr, H. and Uhde, J. (2013) On the Optimal Design of Pension Systems. Empirica, 40, 457-482. https://doi.org/10.1007/s10663-013-9214-2

[13] Podger, A., Stanton, D. and Whiteford, P. (2014) Designing Social Security Systems: Learning from Australia and Other Countries. Public Administration and Development, 34, 231-250. https://doi.org/10.1002/pad.1689

[14] Staubli, S. and Zweimüller, J. (2012) Does Raising the Retirement Age Increase Employment of Older Workers? University of Zurich Department of Economics, Zürich.

[15] Atalay, K. and Barrett, G.F. (2015) The Impact of Age Pension Eligibility Age on Retirement and Program Dependence: Evidence from an Australian Experiment. Review of Economics and Statistics, 97, 71-87. https://doi.org/10.1162/REST_a_00443

[16] Atchley, R.C. (1982) Retirement as Social Institution. Annual Review of Sociology, 8, 263-287. https://doi.org/10.1146/annurev.so.08.080182.001403

[17] Börsch-Supan, A. and Wilke, C.B. (2004) The German Public Pension System: How It Was, How It Will Be (No. W10525). National Bureau of Economic. http://www.nber.org/papers/w10525

[18] Berkel, B. and Börsch-Supan, A. (2004) Pension Reform in Germany: The Impact on Retirement Decisions. FinanzArchiv. Public Finance Analysis, 60, 393-421. https://doi.org/10.1628/0015221042396096

[19] Costa, D.L. (1998) The Evolution of Retirement: An American Economic History, 1880-1990. University of Chicago Press, Chicago, 6-31. https://doi.org/10.7208/chicago/9780226116228.001.0001

[20] Lazear, E.P. (1979) Why Is There Mandatory Retirement? The Journal of Political Economy, 87, 1261-1284. https://doi.org/10.1086/260835

[21] Axelrad, H. and James, J.B. (2016) Employers' Attitudes toward Older-Worker Job Seekers: A Comprehensive Review with Recommendations for Action. Emerald Group Publishing Limited, Bingley, 489-512. https://doi.org/10.1108/978-1-78635-448-820161020

[22] Cutler, D.M. and Lleras-Muney, A. (2012) Education and Health: Insights from International Comparisons (No. w17738). National Bureau of Economic Research.

[23] Holzmann, R. (2000) The World Bank Approach to Pension Reform. International Social Security Review, 53, 11-34. https://doi.org/10.1111/1468-246X.00061

[24] Borowski, A. (2015) Israel's Long-Term Care Social Insurance Scheme after a Quarter of a Century. Journal of Aging and Social Policy, 27, 195-214. https://doi.org/10.1080/08959420.2015.1022101

[25] Organization for Economic Co-Operation and Development (2016) Life Expectancy at Birth. Organization for Economic Co-Operation and Development, Paris.

[26] Top, D.C. and Savu, L. (2014) Considerations Regarding the Equalization of the Retirement Age for Men and Women at 65 Years. Fiat Iustitia, 8, 240-243.

[27] Reznik, G., Shoffner, D. and Weaver, D.A. (2005) Coping with the Demographic 
Challenge: Fewer Children and Living Longer. Social Security Bulletin, 66, 37-45.

[28] Rürup, B. (2002) The German Pension System: Status Quo and Reform Options. Social Security Pension Reform in Europe. University of Chicago Press, Chicago, 137-170. http://www.nber.org/books/feld02-2 https://doi.org/10.7208/chicago/9780226241913.003.0007

[29] Brandon, E. (2010) Why the Retirement Age Is Increasing? U.S. News and World Report, Washington DC, 15 November 2010.

[30] Olsen, H. and Manfredi, T. (2013) Ageing and Employment Policies: Norway 2013: Working Better with Age. Organization for Economic Co-Operation and Development, Paris.

http://www.oecd.org/els/norway-2013-9789264201484-en.htm

[31] Olshansky, S.J., Goldman, D.P. and Rowe, J.W. (2015) Resetting Social Security. Daedalus, 144, 68-79. https://doi.org/10.1162/DAED_a_00331

[32] Yeshiva World News-Israel Desk, Jerusalem (2014) Israel Likely to Raise Retirement Age in 2015 State Budget. The Yeshiva World News, Brooklyn, 26 February 2014.

http://www.theyeshivaworld.com/news/headlines-breaking-stories/215523/israel-lik ely-to-raise-retirement-age-in-2015-state-budget.html

[33] Settergren, O. (2001) The Automatic Balance Mechanism of the Swedish Pension System. Wirtschaftspolitische Blätter, 4, 339-349.

[34] Osterman, P. (2008) College for All? The Labor Market for College Educated Workers. Change the Magazine of Higher Learning, 40, 22-31.

[35] Tishman, F.M., Van, L.S. and Bruyère, S.M. (2012) Employer Strategies for Responding to an Aging Workforce. Rutgers, New Brunswick. http://www.heldrich.rutgers.edu/sites/default/files/products/uploads/NTAR_Emplo yer_Strategies_Report.pdf

[36] Axelrad, H., Luski, I. and Malul, M. (2016) Behavioral Biases in the Labor Market, Differences between Older and Younger Individuals. Journal of Behavioral and $E_{X-}$ perimental Economics, 60, 23-28. https://doi.org/10.1016/j.socec.2015.11.003

[37] Conen, W., Henkens, K. and Schippers, J. (2014) Ageing Organizations and the Extension of Working Lives: A Case Study Approach. Journal of Social Policy, 43, 773792. https://doi.org/10.1017/S0047279414000336

[38] Brunello, G. and Comi, S. (2013) The Side Effect of Pension Reforms on Training: Evidence from Italy. IZA Discussion Papers 7755. Institute for the Study of Labor (IZA). http://hdl.handle.net/10419/89976

[39] Institute of Medicine (US) Committee on the Long-Run Macroeconomic Effects of the Aging U.S. Population (2012) Aging and the Macroeconomy: Long-Term Implications of an Older Population. Financial Analysts Journal, 69, 106-107.

[40] Munnell, A.H. and Steven, S.A. (2008) Rounding out the Picture. Brookings Institution Press, Washington DC, 142-148.

http://www.jstor.org/stable/10.7864/j.ctt6wph6r

[41] European Commission (2001) Guidelines for Member States' Employment Policies for the Year 2002. European Commission, Brussels, 50.

[42] Korczyk, S.M. and Rix, S. (2004) Is Early Retirement Ending? American Association of Retired Persons Public Policy Institute, Washington DC.

[43] Wang, M. and Shultz, K.S. (2010) Employee Retirement: A Review and Recommendations for Future Investigation. Journal of Management, 36, 172-206. https://doi.org/10.1177/0149206309347957

[44] Börsch-Supan, A. and Schuth, M. (2013) Early Retirement, Mental Health and So- 
cial Networks. In Discoveries in the Economics of Aging, University of Chicago Press, 225-250. https://doi.org/10.1515/9783110295467.337

[45] Fernández, J., Alcover, C. and Crego, A. (2013) Psychosocial Profiles of Early Retirees Based on Experiences during Post-Working Life Transition and Adjustment to Retirement. Revista De Psicología Social, 28, 99-112. https://doi.org/10.1174/021347413804756032

[46] Ebbinghaus, B. and Hassel, A. (2000) Striking Deals: Concertation in the Reform of Continental European Welfare States. Journal of European Public Policy, 7, 44-62. https://doi.org/10.1080/135017600343269

[47] Ghilarducci, T. and Moore, K. (2015) The Racial Morbidity Gap: Implications for Raising the Retirement Age.

http://www.economicpolicyresearch.org/images/docs/research/retirement_security/ Moore_Racial_Morbidity_Gap.pdf

[48] Mesa, A.A. and Montecinos, V. (1999) The Privatization of Social Security and Women's Welfare: Gender Effects of the Chilean Reform. Latin American Research Review, 34, 7-37.

[49] Fernandes, D. (2016) Baby Boomer Retirements May Slow Mass. Economic Growth. Boston Globe, Boston, 17 February 2016.

[50] Henkens, K. and Schippers, J. (2012) Employers' Attitudes and Actions towards the Extension of Working Lives in Europe. International Journal of Manpower, 33, 648-665. https://doi.org/10.1108/01437721211261804

[51] Henkens, K. and Schippers, J. (2008) Labor Market Policies Regarding Older Workers in the Netherlands. In: Taylor, P., Eds., Ageing Labor Forces. Promises and Prospects, Edward Elgar, Cheltenham, UK.

[52] Weaver, K. and Willén, A. (2014) The Swedish Pension System after Twenty Years: Mid-Course Corrections and Lessons. OECD Journal on Budgeting, 13, $1 \mathrm{~A}$. https://doi.org/10.1787/budget-13-5jxx3sx58x9t

[53] Redaymulvey, G. (2000) Gradual Retirement in Europe. Journal of Aging and Social Policy, 11, 49-60. https://doi.org/10.1300/J031v11n02_06

[54] Laun, T. and Wallenius, J. (2015) A Life Cycle Model of Health and Retirement: the Case of Swedish Pension Reform. Journal of Public Economics, 127, 127-136. https://doi.org/10.1016/j.jpubeco.2013.11.002

[55] Olofsson, G. (2001) Age, Work and Retirement in Sweden-Views, Policies and Strategies of Key Actors. Proceedings of the Swedish Case for the "Millennium Project" Conference, Tokyo, 29-30 November 2001, 29-30.

[56] Barr, N. (2006) Pensions: Overview of the Issues. Oxford Review of Economic Policy, 22, 1-14. https://doi.org/10.1093/oxrep/grj001

[57] Social Security Administration (US). https://www.ssa.gov/policy/docs/progdesc/ssptw/index.html 
Submit or recommend next manuscript to SCIRP and we will provide best service for you:

Accepting pre-submission inquiries through Email, Facebook, LinkedIn, Twitter, etc. A wide selection of journals (inclusive of 9 subjects, more than 200 journals)

Providing 24-hour high-quality service

User-friendly online submission system

Fair and swift peer-review system

Efficient typesetting and proofreading procedure

Display of the result of downloads and visits, as well as the number of cited articles Maximum dissemination of your research work

Submit your manuscript at: http://papersubmission.scirp.org/

Or contact jss@scirp.org 